\title{
Ludwigite from central Sweden: new data and crystal structure refinement
}

\author{
P. W. U. APPEL ${ }^{1}$ and M. F. BrigatTI ${ }^{2}$ \\ ${ }^{1}$ Geological Survey of Denmark and Greenland, Thoravej 8, DK-2400 NV, Copenhagen, Denmark \\ 2 Dipartimento di Scienze della Terra, Università di Modena, Largo S. Eufemia 19, I-41100, Modena, Italy
}

\section{ABSTRACT}

Ludwigite from B-bearing iron ores in the Bergslagen area of central Sweden and in the coastal area north of Stockholm has been studied using chemical and single-crystal diffraction techniques. Structure refinements, completed for three crystals showing slightly different $\mathrm{Al}$ contents, in the space group Pbam (agreement factor: $2.42 \leqslant R \leqslant 2.79$ ) indicate that: (1) octahedral M1, M2 and M3 bond distances are similar, although the calculated site population suggests that $\mathrm{Ml}$ and $\mathrm{M} 2$ are nearly completely occupied by $\mathrm{Mg}$ whereas $\mathrm{M} 3$ also contains $\mathrm{Fe}^{2 \cdot}$ and $\mathrm{Fe}^{3+} ;(2)$ in the $\mathrm{M} 4$ octahedron $\mathrm{Fe}^{3+}$ and $\mathrm{Al}$ dominate over $\mathrm{Mg}$ (and $\mathrm{Fe}^{2+}$ ); and (3) the distortion parameter, $\mathrm{BLD}$, indicates that $\mathrm{M} 3$ is the most regular, whereas $\mathrm{M} 4$ is the most distorted octahedron.

KeYwords: ludwigite, Tallgruvan, Sweden, borates, chemistry, structure refinement.

\section{Introduction}

DURING geological and mineralogical investigations of B-bearing iron ores in the Bergslagen area of central Sweden and in the coastal area north of Stockholm, ludwigite crystals were found in mining dumps from two abandoned iron mines: Tallgruvan and Stabby gruvan. They were studied by optical, chemical and crystal structure analysis.

Ludwigite is the $\mathrm{Mg}^{2+}, \mathrm{Fe}^{3+}$ borate endmember (ideal formula $\mathrm{Mg}_{2} \mathrm{Fe}^{3+} \mathrm{O}_{2}\left[\mathrm{BO}_{3}\right]$ ) of the ludwigite mineral group (general formula $X_{2} \mathrm{YO}_{2}\left[\mathrm{BO}_{3}\right]$ where $X=\mathrm{Mg}^{2+}, \mathrm{Fe}^{2--}, \mathrm{Ni}^{2+} ; Y=$ $\mathrm{Al}^{3+}, \mathrm{Fe}^{3+}, \mathrm{Mn}^{3+}, \mathrm{Mn}^{2+}, \mathrm{Ti}^{4+}, \mathrm{Mg}^{2+}, \mathrm{Sb}^{3+}$ (Fleischer and Mandarino, 1995). It is generally found in high temperature metamorphic rocks, in skarns and in iron and tin ores (Anovitz and Grew, 1996).

The ludwigite structure (space group Pham) was determined for the first time by Takéuchi et al. (1950) and subsequently refined by Bertaut (1950), Cavalho da Silva et al. (1955), Mokeyeva (1968), Bonazzi and Menchetti (1989), Norrestam et al. (1989a,b), Takéuchi and Kogure (1992).

Hawthorne et al. (1996) classified ludwigite into " $3 \AA$ wallpaper structures" borates.
Actually, the prominent feature in the mineral structure is a chain of edge-sharing octahedra $\left[\mathrm{M} \phi_{4}, \phi=\mathrm{O}^{-2}\right]$ with a repeat distance of $\sim 3 \AA$ along its length. The chain forms zigzag sheets, five (denoted F walls by Takéuchi et al, 1950) and three (C walls) octahedra wide that interlock so that there are triangular tunnels containing $\mathrm{B} \phi_{3}$ groups (Fig. 1).

The occurrence of this mineral in central Sweden provided us with the opportunity to compare the crystal chemical characteristics of this ludwigite with samples from other localities and to investigate the octahedral cation order in the structure.

\section{Geological setting}

Boron-bearing iron-formations occur in the Bergslagen area of central Sweden and in the coastal area north of Stockholm. These areas consist of banded gneisses with large tracts of metavolcanic rocks and metasediments. The metavolcanic rocks comprise acid lavas and tuffs, the so-called leptites, as well as minor amphibolites representing intrusive mafic volcanic rocks. Beds of sedimentary rocks such 


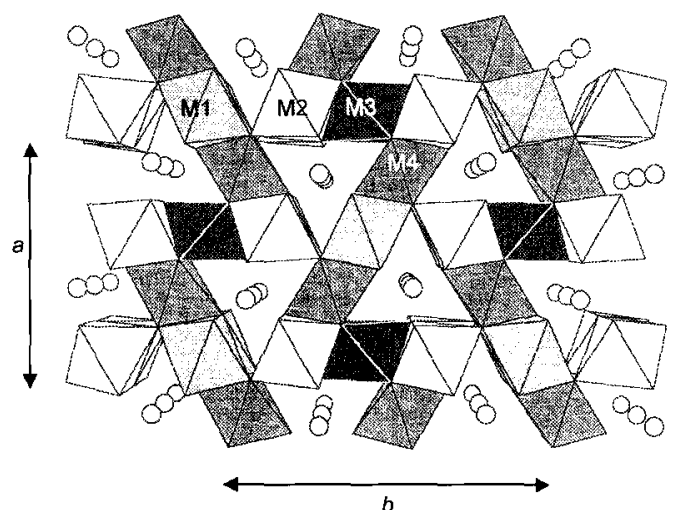

Fig. 1. Polyhedral drawing of the Mg-Fe-ludwigite structure viewed along the $c$-axis showing the flat and zigzag walls of edge-sharing octahedra. The circles represent $\mathrm{B}$ positions. The unit-cell and the nomenclature used for the metal position are indicated.

as cordierite schists, quartzites, limestone and dolomite as well as numerous beds of banded iron-formations are intercalated in the leptites. The volcanic rocks and the sediments have been intruded by granites. Subsequently the area was repeatedly deformed and metamorphosed up to amphibolite-facies conditions.

Iron-formations are abundant in the Bergslagen area and these have been mined for many hundreds of years. The most common type of iron-formation is a quartz-magnetite-bearing ironformation, found locally with hematite instead of magnetite. High-Mn iron-formations are also frequently encountered. Boron-bearing ironformations are found as beds which can be traced for kilometres along strike, mostly hosted in carbonate beds. The strike of the B-bearing iron-formations is parallel to the general strike of the metavolcanic rocks and metasediments. The thickness of the beds has not been determined due to a poor degree of exposure. The best-studied deposit of B-bearing iron-formation is Tallgruvan, which is situated in the Norberg area of Bergslagen. Tallgruvan, which is an abandoned iron mine, occurs in dolomite close to the contact with one of the late intrusive granites. Geijer $(1927,1939)$ regarded the ore body as a replacement of dolomite with the metals and the $\mathrm{B}$ being derived from the nearby granite. This has been debated by Magnusson (1929), who regarded iron-formations as submarine exhalative precipitates with little metasomatic imprint.

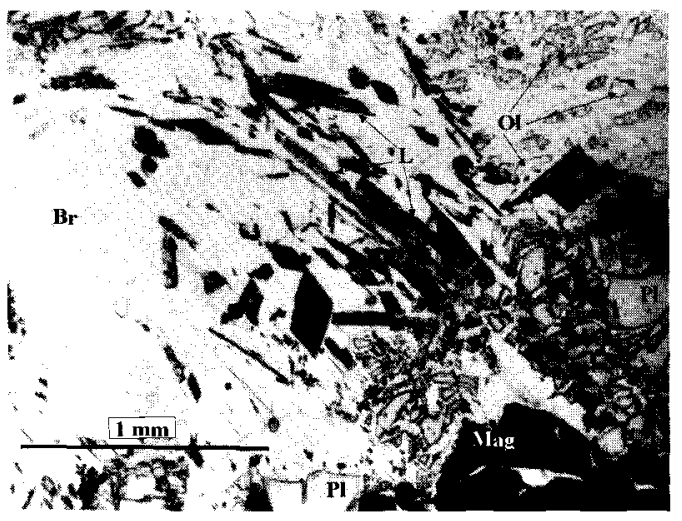

FIG. 2. Photomicrograph of B-bearing iron ore from Stabby gruvan, north of Stockholm. L: ludwigite, Ol: olivine, Br: brucite, $\mathrm{Pl}$ : pleonaste, Mag: magnetite. Sample 450576.

\section{Paragenesis}

The B-bearing iron-formation at Tallgruvan displays a complex mineral assemblage. It is a medium-grained rock consisting of forsterite (containing up to $58 \mathrm{wt} \% \mathrm{MgO}$ ), magnetite, calcite, dolomite, spinel, ludwigite \pm fluoborite and szajbelyite (Geijer 1927, 1939). Ludwigite from Tallgruvan has been reported recently by Anovitz and Grew (1996). Most of the minerals have been partly altered to a fine-grained assemblage of serpentine and other unidentified minerals.

Ludwigite occurs mainly as spindle-shaped grains up to $5 \mathrm{~mm}$ long and $<1 \mathrm{~mm}$ across (Fig. 2), but also occurs in stubby prisms up to $7 \mathrm{~mm}$ in cross section (Fig. 2). It is strongly pleochroic with colours ranging from bright green to dark green to very dark brown, and is altered to a fine-grained assemblage of B-bearing minerals and magnetite (Fig. 3).

Ludwigite from three samples has been investigated for this study. Samples 450514A and 450540 are from Tallgruvan from dumps $\sim 100 \mathrm{~m}$ apart. Sample 450576 is from Stabby gruvan, north of Stockholm.

\section{Experimental}

Back-scattered electron images and X-ray maps on several ludwigite crystals (Philips SEM XL-40 equipped with energy dispersive electron micro- 


\section{LUDWIGITE FROM CENTRAL SWEDEN}

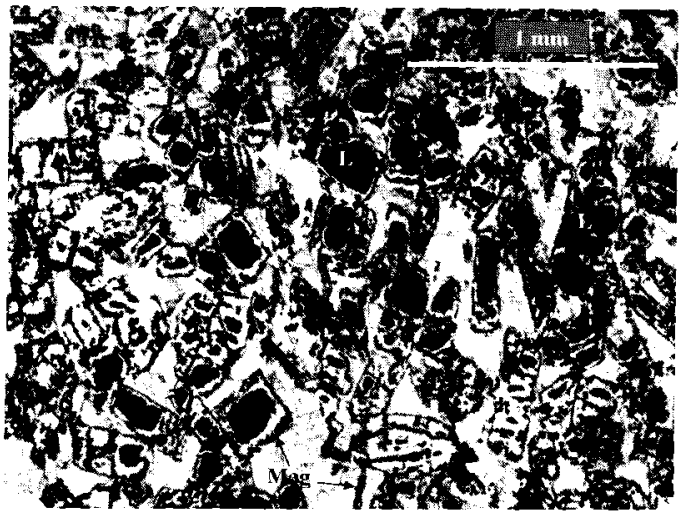

Fig. 3. Photomicrograph of B-bearing iron ore from Tallgruvan, Norberg with stubby prisms of ludwigite partly altered to a transparent B-bearing mineral and magnetite. L: ludwigite, Mag: magnetite. Sample 450514 .

probe EDS-EDAX 9900) did not reveal $\mathrm{Mg}$ and Fe zoning. Therefore, three crystals from crushed rock samples (samples 450514A, 450540 and 450576) were selected for the structural study and mounted on a Siemens P4P rotating-anode single crystal diffractometer operating at $50 \mathrm{kV}$ and

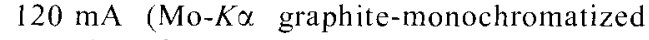
radiation, $\lambda=0.71073)$ and equipped with XSCANS software (Siemens, 1993). Cell dimensions (Table 1) were determined by the leastsquare refinement of 45 automatically aligned reflections with $15^{\circ} \leqslant 2 \theta \leqslant 30^{\circ}$. These values are given in Table 1, together with other information pertinent to X-ray data measurement and structure refinement. Intensities were measured from 3.5 to $70^{\circ} 2 \theta \quad(-14 \leqslant h \leqslant 14$, $0 \leqslant k \leqslant 19,0 \leqslant l \leqslant 4$ ) by $\omega$ scan mode. Psi-scan data were measured on 10 strong uniformly distributed reflections with regard to $2 \theta\left(\chi>80^{\circ}\right)$ at $10^{\circ}$ intervals of $\phi$. The intensities were corrected for absorption, Lorentz-polarization and background effects, and then averaged and reduced to structure factors. A reflection was classed as observed if its intensity exceeded that of $3 \sigma$ based on counting statistics.

The SHELX-97 system of programs (Sheldrick, 1997) was used for the computational procedures. Refinements were initiated using the atomic positions of ludwigite reported by Takéuchi and Kogure (1992).

Scattering curves together with anomalous dispersion corrections were taken from Ibers and Hamilton (1974). Neutral B, half-ionized O, and fully ionized $M$ cation scattering factors were used. The curves for the octahedral $\mathrm{M}$ atoms, at the early stages of refinement, were: $\mathrm{Mg}^{2+}$ for $\mathrm{Ml}$, $\mathrm{M} 2$ and M3 sites, whereas $\mathrm{Fe}^{3+}$ was considered to fully occupy M4 site. Site occupancy refinement revealed that $\mathrm{M} 3$ was greater than, whereas M4 was less than the ideal occupancy, suggesting excess and deficiencies in the scattering power, respectively. In the last phase of anisotropic refinement, mixed scattering curves appropriate to the composition of each site were applied and a

TABLE 1. Data collection and refinement of the ludwigite crystals

\begin{tabular}{|c|c|c|c|}
\hline Sample & $450514 \mathrm{~A}$ & 450540 & 450576 \\
\hline$A(\AA)$ & $9.254(1)$ & $9.248(1)$ & $9.259(1)$ \\
\hline$B(\AA)$ & $12.287(1)$ & $12.276(1)$ & $12.283(1)$ \\
\hline$C(\AA)$ & $3.004(1)$ & $3.0050(3)$ & $3.005(1)$ \\
\hline$V(\AA)^{3}$ & 341.6 & 341.2 & 341.8 \\
\hline Crystal dimensions $(\mu \mathrm{m})$ & $40 \times 80 \times 100$ & $40 \times 100 \times 120$ & $40 \times 60 \times 180$ \\
\hline Radiation & $\mathrm{Mo}_{0}-K \alpha$ & $\mathrm{Mo}-K \alpha$ & Mo- $K \alpha$ \\
\hline $2 \theta$-range () & $3.5-70$ & $3.5-70$ & $3.5-70$ \\
\hline Scan type and scan width $\left({ }^{\circ}\right)$ & $\omega, 1.30$ & $\omega, 1.16$ & $\omega, 1.00$ \\
\hline No. of unique reflections & 824 & 836 & 851 \\
\hline $\mathrm{R}_{\mathrm{int}}(\%)$ & 2.73 & 2.57 & 2.60 \\
\hline No. of observed reflections $(F>5 \sigma(F))$ & 672 & 739 & 761 \\
\hline Final $\mathrm{R}$ for all observed reflections $(\%)$ & 2.79 & 2.42 & 2.51 \\
\hline
\end{tabular}

Note: $\mathrm{R}_{\text {int }}=\Sigma \mid\left(\mathrm{F}_{h k l}^{2}-\mathrm{F}_{\text {mean }}^{2}\right) / \Sigma\left[\mathrm{F}_{\text {mean }}^{2}\right]$ where $\mathrm{F}_{\text {mean }}=\left(\mathrm{F}_{h k l}+\mathrm{F}_{\overline{h k l}}\right) / 2$

Final discrepancy index expressed as $R_{o b s}=\Sigma|| F_{o}|-| F_{c}|/ \Sigma| F_{o} \mid$ 


\section{P.W. U. APPEL AND M. F. BRIGATTI}

difference Fourier synthesis was calculated. Highest positive peaks in the final differenceFourier maps, i.e. $0.58,0.53$ and $0.50 \mathrm{e}^{-} / \AA^{3}$ for samples 450514A, 450540 and 450576, respectively, are between metal and $O$ positions, representing bonding electrons.

Full-matrix least-square refinements of all variables (including site occupancies of $M$ sites) converged to the $\mathrm{R}$ indices given in Table 1. Final atomic coordinates and equivalent isotropic displacement factors are given in Table 2. Selected interatomic distances, angles and distortion parameters are listed in Table 3 and refined site-scattering values for $M$ sites in e.p.f.u. (electrons per formula unit) are given in Table 4 . The structure factor tables are available on request from the Editor. Subsequent to the crystallographic work, the crystals used in the collection of the intensity data were mounted in epoxy, polished and analysed by electron microprobe. The compositions were determined using an ARL-SEMQ microprobe operated in wavelength-dispersion mode. The acceleration voltage was $20 \mathrm{kV}$, and the beam current was $15 \mathrm{nA}$. Multiple points were analysed for each sample; average values for each sample are reported in

TABLE 2. Positional, isotropic and anisotropic $\left(\AA^{2}\right)$ thermal factors of ludwigite crystals

\begin{tabular}{|c|c|c|c|c|c|c|c|c|}
\hline & $\mathrm{x} / a$ & $\mathrm{y} / b$ & $\mathrm{z} / \mathrm{c}$ & $\mathrm{B}_{\mathrm{cq}}$ & $\mathrm{B}_{11}$ & $\mathrm{~B}_{22}$ & $\mathrm{~B}_{33}$ & $\mathrm{~B}_{12}$ \\
\hline \multicolumn{9}{|c|}{ Sample 450514A } \\
\hline B & $0.2733(3)$ & $0.3598(2)$ & 0 & $0.50(7)$ & $0.56(9)$ & $0.57(9)$ & $0.4(1)$ & $-0.02(7)$ \\
\hline M1 & 0 & 0 & $1 / 2$ & $0.46(4)$ & $0.36(5)$ & $0.46(5)$ & $0.55(6)$ & $-0.05(3)$ \\
\hline M2 & $0.0015(1)$ & $0.28077(8)$ & $1 / 2$ & $0.38(3)$ & $0.33(3)$ & $0.40(3)$ & $0.42(4)$ & $0.05(2)$ \\
\hline M3 & $1 / 2$ & 0 & 0 & $0.45(3)$ & $0.49(4)$ & $0.30(3)$ & $0.56(5)$ & $0.00(2)$ \\
\hline M4 & $0.23873(4)$ & $0.11554(3)$ & 0 & $0.36(1)$ & $0.31(1)$ & $0.40(1)$ & $0.38(2)$ & $-0.06(1)$ \\
\hline 01 & $0.3498(2)$ & $0.4572(2)$ & 0 & $0.50(5)$ & $0.44(6)$ & $0.39(6)$ & $0.67(8)$ & $-0.12(5)$ \\
\hline $\mathrm{O} 2$ & $0.1089(2)$ & $0.1430(2)$ & $1 / 2$ & $0.53(5)$ & $0.51(7)$ & $0.56(6)$ & $0.51(8)$ & $0.04(5)$ \\
\hline $\mathrm{O} 3$ & $0.1245(2)$ & $0.3578(2)$ & 0 & $0.51(5)$ & $0.38(6)$ & $0.51(6)$ & $0.64(8)$ & $0.00(5)$ \\
\hline O4 & $0.3826(2)$ & $0.0765(2)$ & $1 / 2$ & $0.60(5)$ & $0.52(6)$ & $0.51(6)$ & $0.75(9)$ & $0.01(5)$ \\
\hline $\mathrm{O5}$ & $0.3496(2)$ & $0.2624(2)$ & 0 & $0.51(5)$ & $0.55(6)$ & $0.36(6)$ & $0.62(9)$ & $0.05(5)$ \\
\hline \multicolumn{9}{|c|}{ Sample 450540} \\
\hline B & $0.2734(3)$ & $0.3599(2)$ & 0 & $0.35(6)$ & $0.37(7)$ & $0.43(7)$ & $0.27(9)$ & $-0.05(5)$ \\
\hline M1 & 0 & 0 & $1 / 2$ & $0.42(3)$ & $0.31(4)$ & $0.41(4)$ & $0.53(5)$ & $-0.07(3)$ \\
\hline M2 & $0.00145(9)$ & $0.28071(7)$ & $1 / 2$ & $0.43(2)$ & $0.30(3)$ & $0.42(3)$ & $0.56(3)$ & $0.07(2)$ \\
\hline M3 & $1 / 2$ & 0 & 0 & $0.43(2)$ & $0.39(3)$ & $0.38(3)$ & $0.51(4)$ & $-0.01(2)$ \\
\hline M4 & $0.23883(4)$ & $0.11549(3)$ & 0 & $0.32(1)$ & $0.18(1)$ & $0.39(1)$ & $0.39(1)$ & $-0.06(1)$ \\
\hline O1 & $0.3500(2)$ & $0.4569(1)$ & 0 & $0.45(4)$ & $0.37(5)$ & $0.42(5)$ & $0.57(6)$ & $-0.01(4)$ \\
\hline $\mathrm{O} 2$ & $0.1090(2)$ & $0.1427(1)$ & $1 / 2$ & $0.44(4)$ & $0.32(5)$ & $0.45(5)$ & $0.54(6)$ & $0.05(4)$ \\
\hline $\mathrm{O} 3$ & $0.1247(2)$ & $0.3579(1)$ & 0 & $0.48(4)$ & $0.23(5)$ & $0.52(5)$ & $0.70(7)$ & $-0.04(4)$ \\
\hline O4 & $0.3826(2)$ & $0.0768(1)$ & $1 / 2$ & $0.51(4)$ & $0.30(5)$ & $0.45(5)$ & $0.78(7)$ & $-0.01(4)$ \\
\hline O5 & $0.3499(2)$ & $0.2625(1)$ & 0 & $0.42(4)$ & $0.35(5)$ & $0.40(5)$ & $0.52(7)$ & $0.09(4)$ \\
\hline \multicolumn{9}{|c|}{ Sample 450576} \\
\hline B & $0.2736(3)$ & $0.3600(2)$ & 0 & $0.32(6)$ & $0.30(7)$ & $0.46(7)$ & $0.21(8)$ & $0.05(5)$ \\
\hline M1 & 0 & 0 & $1 / 2$ & $0.28(3)$ & $0.22(4)$ & $0.30(4)$ & $0.31(5)$ & $-0.07(3)$ \\
\hline M2 & $0.00132(8)$ & $0.28086(7)$ & $1 / 2$ & $0.30(2)$ & $0.26(3)$ & $0.28(3)$ & $0.35(3)$ & $0.07(2)$ \\
\hline M3 & $1 / 2$ & 0 & 0 & $0.39(2)$ & $0.43(3)$ & $0.32(3)$ & $0.42(3)$ & $0.01(2)$ \\
\hline M4 & $0.23830(4)$ & $0.11577(3)$ & 0 & $0.26(1)$ & $0.18(1)$ & $0.32(1)$ & $0.26(1)$ & $-0.05(1)$ \\
\hline $\mathrm{O} 1$ & $0.3500(2)$ & $0.4572(1)$ & 0 & $0.41(4)$ & $0.38(5)$ & $0.35(5)$ & $0.50(6)$ & $-0.08(4)$ \\
\hline $\mathrm{O} 2$ & $0.1092(2)$ & $0.1429(1)$ & $1 / 2$ & $0.44(4)$ & $0.45(5)$ & $0.35(5)$ & $0.52(6)$ & $0.03(4)$ \\
\hline $\mathrm{O} 3$ & $0.1242(2)$ & $0.3579(1)$ & 0 & $0.41(4)$ & $0.27(5)$ & $0.46(5)$ & $0.49(6)$ & $0.02(4)$ \\
\hline O4 & $0.3827(2)$ & $0.0764(1)$ & $1 / 2$ & $0.45(4)$ & $0.31(5)$ & $0.37(5)$ & $0.68(6)$ & $-0.02(4)$ \\
\hline O5 & $0.3493(2)$ & $0.2625(1)$ & 0 & $0.42(4)$ & $0.41(5)$ & $0.29(4)$ & $0.56(6)$ & $0.08(4)$ \\
\hline
\end{tabular}

Note: the form of the anisotropic thermal parameter is:

$\exp \left[-1 / 4\left(\mathrm{~B}_{11} h^{2} a^{*^{2}}+\mathrm{B}_{22} k^{2} b^{* 2}+\mathrm{B}_{33} l^{2} c^{2}+2 \mathrm{~B}_{12} h k a^{*} b^{*}+2 \mathrm{~B}_{13} h l a^{*} c^{*}+2 \mathrm{~B}_{23} k l b^{*} c^{*}\right)\right]$.

$\mathrm{B}_{13}=\mathrm{B}_{23}=0$ 


\section{LUDWIGITE FROM CENTRAL SWEDEN}

TABLE 3. Selected interatomic distances $(\AA)$ and distortion parameters of coordination polyhedra $(\mathrm{BLD} \%)$ in ludwigite crystals

\begin{tabular}{llll}
\hline Sample & $450514 \mathrm{~A}$ & 450540 & 450576 \\
$-\mathrm{B}-\mathrm{O} 1$ & $1.390(3)$ & $1.385(3)$ & $1.388(3)$ \\
$\mathrm{B}-\mathrm{O} 3$ & $1.377(3)$ & $1.375(3)$ & $1.383(3)$ \\
$\mathrm{B}-\mathrm{O} 5$ & $1.389(3)$ & $1.389(3)$ & $1.388(3)$ \\
$<\mathrm{B}-\mathrm{O}>$ & 1.385 & 1.383 & 1.386 \\
$\mathrm{BLD}$ & 0.41 & 0.39 & 0.17 \\
$\mathrm{M} 1-\mathrm{O} 1(\times 4)$ & $2.113(1)$ & $2.112(1)$ & $2.112(1)$ \\
$\mathrm{M} 1-\mathrm{O} 2(\times 2)$ & $2.026(2)$ & $2.021(2)$ & $2.026(2)$ \\
$<\mathrm{M} 1-\mathrm{O}>$ & 2.084 & 2.082 & 2.083 \\
$\mathrm{BLD}$ & 1.85 & 1.94 & 1.84 \\
$\mathrm{M} 2-\mathrm{O} 2$ & $1.963(2)$ & $1.965(2)$ & $1.967(2)$ \\
$\mathrm{M} 2-\mathrm{O} 3(\times 2)$ & $2.109(1)$ & $2.110(1)$ & $2.109(1)$ \\
$\mathrm{M} 2-\mathrm{O} 4$ & $2.070(2)$ & $2.066(2)$ & $2.069(2)$ \\
$\mathrm{M} 2-\mathrm{O} 5(\times 2)$ & $2.124(1)$ & $2.122(1)$ & $2.126(1)$ \\
$<\mathrm{M} 2-\mathrm{O}>$ & 2.083 & 2.081 & 2.084 \\
$\mathrm{BLD} \mathrm{D}_{\mathrm{M} 2}$ & 2.14 & 2.17 & 2.13 \\
$\mathrm{M} 3-\mathrm{O} 3(\times 2)$ & $2.093(2)$ & $2.091(2)$ & $2.090(2)$ \\
$\mathrm{M} 3-\mathrm{O} 4(\times 4)$ & $2.078(1)$ & $2.080(1)$ & $2.078(1)$ \\
$<\mathrm{M} 2-\mathrm{O} 3>$ & 2.083 & 2.084 & 2.082 \\
$\mathrm{BLD} \mathrm{M}_{\mathrm{M}}$ & 0.32 & 0.24 & 0.26 \\
$\mathrm{M} 4-\mathrm{O} 1$ & $2.111(2)$ & $2.113(2)$ & $2.112(2)$ \\
$\mathrm{M} 4-\mathrm{O} 2(\times 2)$ & $1.953(1)$ & $1.952(1)$ & $1.949(1)$ \\
$\mathrm{M} 4-\mathrm{O} 4(\times 2)$ & $2.064(1)$ & $2.062(1)$ & $2.068(1)$ \\
$\mathrm{M} 4-\mathrm{O} 5$ & $2.076(2)$ & $2.077(2)$ & $2.074(2)$ \\
$<\mathrm{M} 4-\mathrm{O}>$ & 2.037 & 2.036 & 2.037 \\
$\mathrm{BLD}$ M4 & 2.74 & 2.77 & 2.86 \\
& & & \\
\hline
\end{tabular}

Note: Standard deviations are in parentheses;

$$
\mathrm{BLD}=\frac{100}{n} \sum_{i=1}^{n} \frac{\left((X-\mathrm{O})_{i}-<X-\mathrm{O}\right\rangle \mid}{\langle X-\mathrm{O}\rangle} \%
$$

where $n$ is the number of bonds and $X-O$ the cationanion bond distance (Renner and Lehmann, 1986).

TABLE 4. Refined site scattering values (XREF, electrons per formula unit (e.p.f.u.)) and equivalent electrons from the unit formulae (EPMA) of Table 5 for octahedral sites in studied ludwigite crystals

\begin{tabular}{lccc}
\hline Sample & $450514 \mathrm{~A}$ & 450540 & 450576 \\
\hline M1 XREF & $6.03(4)$ & $6.01(3)$ & $6.02(3)$ \\
M2 XREF & $12.0(6)$ & $12.02(3)$ & $12.0(6)$ \\
M3 XREF & $7.49(4)$ & $7.70(4)$ & $7.52(4)$ \\
M4 XREF & $23.7(1)$ & $23.75(6)$ & $23.18(8)$ \\
$\Sigma[\mathrm{M} 1, \mathrm{M} 2, \mathrm{M} 3, \mathrm{M} 4]_{\mathrm{XREF}}$ & 49.2 & 49.5 & 48.7 \\
{$[\mathrm{M} 1, \mathrm{M} 2, \mathrm{M} 3, \mathrm{M} 4]_{\mathrm{EPMA}}$} & 49.4 & 49.5 & 48.5 \\
\hline
\end{tabular}

Table 5, together with the unit formulae calculated on the basis of 5 oxygens and the $\mathrm{Fe}^{2+} / \mathrm{Fe}^{3+}$ ratio derived from the crystal-structure refinement. The concentration of B was estimated by stoichiometry from the results of the crystal structure analysis following suggestions by Hawthorne and Grice (1990).

\section{Site population}

The structure refinement verifies that the polyhedral arrangement of the studied ludwigites is similar to that of other previously studied crystals. Consequently the discussion will be limited to a comparative analysis of coordination polyhedra, to their site population and to a description of the main differences with respect to other ludwigites and some isomorphous minerals (Swinnea and Steinfink, 1983; Bonazzi and Menchetti, 1989; Norrestam et al., 1989a,b; Takéuchi and Kogure, 1992; Burns et al., 1994). The site nomenclature we adopted follows that of Takéuchi and Kogure (1992); the polyhedral geometry of the structure is shown in Fig. 1.

TABLE 5. Chemical composition and unit formulae of ludwigite crystals

\begin{tabular}{lrrr}
\hline Sample & $450514 \mathrm{~A}$ & 450540 & 450576 \\
\hline Oxide (wt.\%) & & & \\
$\mathrm{MgO}$ & 39.93 & 40.26 & 41.44 \\
$\mathrm{MnO}$ & 0.04 & 0.06 & 0.25 \\
$\mathrm{FeO}$ & 1.12 & 1.00 & 0.13 \\
$\mathrm{Fe}_{2} \mathrm{O}_{3}$ & 38.50 & 38.49 & 36.50 \\
$\mathrm{Al}_{2} \mathrm{O}_{3}$ & 2.35 & 2.10 & 2.95 \\
$\mathrm{TiO}_{2}$ & 0.08 & 0.10 & 0.47 \\
$\mathrm{SiO}_{2}$ & 0.17 & 0.10 & 0.19 \\
$\mathrm{~B}_{2} \mathrm{O}_{3}$ & 17.82 & 17.89 & 18.05 \\
$\mathrm{Total}$ & 100.01 & 100.00 & 99.98 \\
a.p.f.u. based on & 5 oxygens & & \\
$\mathrm{Mg}^{2+}$ & 1.925 & 1.940 & 1.975 \\
$\mathrm{Mn}^{2+}$ & - & 0.002 & 0.008 \\
$\mathrm{Fe}^{2+}$ & 0.030 & 0.028 & 0.002 \\
$\mathrm{Fe}^{3+}$ & 0.938 & 0.935 & 0.878 \\
$\mathrm{Al}^{3+}$ & 0.090 & 0.080 & 0.110 \\
$\mathrm{Ti}^{4+}$ & 0.002 & 0.002 & 0.012 \\
$\mathrm{Si}^{\mathrm{B}}$ & 0.005 & 0.002 & 0.005 \\
& 0.995 & 0.998 & 0.998 \\
\hline
\end{tabular}




\section{Triangular coordinated sites}

The ludwigite crystals studied present a very small amount of $\mathrm{Si}$ ( $\mathrm{Si}<0.01$ a.p.f.u.) which was assigned to tetrahedral sites by analogy with mixed oxyanion borate minerals (Hawthorne, 1986; Hawthorne et al., 1996). We could make the hypothesis that, as with cuspidine (Merlino and Perchiazzi, 1988), by substituting $\left(\mathrm{Si}_{2} \mathrm{O}_{7}\right)^{6-}$ groups for $\left(\mathrm{B}_{2} \mathrm{O}_{6}\right)^{6 \cdots}$ groups along the [001] direction the sequence ... $\mathrm{B} \square \mathrm{B} \square \mathrm{B} \square \ldots$ is changed to ...SiOSi $\square \mathrm{SiOSi} \square \ldots$

The mean distance $(1.383 \leqslant \mathrm{~B}-\mathrm{O} \leqslant 1.386 \AA)$ is slightly $>1.370 \AA$ (i.e. the grand $\left\langle{ }^{[3]} \mathrm{B} \phi>\right.$ distance reported by Hawthorne et al., 1996), and is similar to the ones reported previously for ludwigite and other isomorphous minerals: e.g. $\langle\mathrm{B}-\mathrm{O}\rangle=1.379$ and $1.383 \AA$ in vonsenite crystals (Bonazzi and Menchetti, 1989); $\langle\mathrm{B}-\mathrm{O}\rangle=1.383 \AA$ in fredrikssonite (Burns et al., 1994); $\angle \mathrm{B}-\mathrm{O}>=1.384 \AA$ in ludwigite (Takéuchi and Kogure, 1992).

The $\mathrm{B}-\mathrm{O} 3$ bond distance is always smaller than $\mathrm{B}-\mathrm{O} 1$ and $\mathrm{B}-\mathrm{O} 5$ and seems to increase according to the trivalent cation substitution at the M3 site.

\section{The $M(1,2,3,4)$ sites}

The $M$ site populations were assigned by combining, in a system of equations, the results of both microprobe analyses and structure refinement (mean electron counts and mean distances $\langle\mathrm{M}-\mathrm{O}>$ ) and taking into account the charge-balance requirements. The best fraction $x_{\mathrm{i}}$ for each species was determined by determining which vector best fits an overdetermined equation system $A x=b$. In order to find out the vector which best fits the present system, we employed the technique of the least-squares, calculating the minimum for the function $F(x)=R^{T} R(R=$ $A x-b$ ). The goodness of the fit between observed and calculated values of chemical and structural parameters was evaluated by the $Q$ parameter $\left(Q=\|b-a x\|_{2}^{2}\right)$. The ideal $<\mathrm{M}-\mathrm{O}>$ mean bond distances were those calculated experimentally for end-member borates (i.e. $\langle\mathrm{Mg}-\mathrm{O}\rangle=$ $2.079 \AA$; Burns et al., 1994; <Al-O $>=$ $1.916 \AA$, Moore and Araki, 1976; $<\mathrm{Fe}^{3+}-\mathrm{O}>=$ $2.065 \AA ;<\mathrm{Fe}^{2+}-\mathrm{O}>=2.147 \AA$; Swinnea and Steinfink, 1983; Venkatakrishnan and Buerger, 1972). To reduce chemical variables the following constraints were adopted: (1) $M$ sites were considered completely filled; (2) $\mathrm{Mn}$ was considered as $\mathrm{Mn}^{2+}$ and $\mathrm{Ti}$ as $\mathrm{Ti}^{4+}$ and they were added to $\mathrm{Fe}^{2+}$ and $\mathrm{Fe}^{3+}$ respectively (note that the $\mathrm{Mn}$ and $\mathrm{Ti}$ amounts are small, so this assumption does not introduce significant errors into the site occupancy calculation); and (3) $\mathrm{Mg}$, $\mathrm{Al}, \mathrm{Fe}^{3+}$ and $\mathrm{Fe}^{2+}$ were considered randomly distributed over the $\mathrm{M}$ sites.

The calculated site population is reported in Table 5. The goodness of fit was $8.4 \times 10^{-5}$, $1.0 \times 10^{-4}$ and $6.6 \times 10^{-5}$, for sample $450514 \mathrm{~A}$, 450540 and 450576 , respectively.

In the studied samples $\langle\mathrm{M} 1-\mathrm{O}\rangle,\langle\mathrm{M} 2-\mathrm{O}\rangle$ and $<\mathrm{M} 3-\mathrm{O}>$ mean bond distances are similar (Table 3), however, the examination of the mean electron count at each site suggests that MI and M2 are almost completely occupied by $\mathrm{Mg}$ whereas M3 contains $\sim 25 \%$ of a heavier cation. The calculated M3 site population is consistent with the presence of $\mathrm{Fe}^{3+}$ together with small amounts of $\mathrm{Fe}^{2+}$. The central cation off-centre shift (BLD parameter, Table 3) is greater in M3 than in $\mathrm{Ml}$ and $\mathrm{M} 2$ sites. The difference in distortion between M1 and M2 sites showing the same population, may be related to the different point symmetry. Actually M1, which lies on $2 / m$, is less distorted than M2, which lies on $m$. The difference between M1 and M3 sites, both of which lie on $2 / m$-point symmetry, may be related to differences in population (Table 6) or to the different octahedral environment: M3 with M2 forms the $\mathrm{C}$ walls with the octahedral sequence M2-M3-M2, whereas M1 with M2 and M4 forms the $\mathrm{F}$ walls with the sequence M2-M4-M1-M4M2 (Fig.1). The $\langle\mathrm{M} 1-\mathrm{O}\rangle$ and $\langle\mathrm{M} 2-\mathrm{O}\rangle$ mean bond lengths are similar to the ones reported for

TABlE 6. Calculated octahedral site population (a.p.f.u.) for ludwigite crystals

\begin{tabular}{llccc}
\hline Site & Species & 450514 & 450540 & 450576 \\
\hline $\mathrm{M} 1$ & $\mathrm{Mg}$ & 0.498 & 0.497 & 0.496 \\
& $\mathrm{Fe}^{2+}$ & 0.002 & 0.002 & 0.003 \\
$\mathrm{M} 2$ & $\mathrm{Mg}$ & 0.997 & 0.997 & 0.999 \\
& $\mathrm{Fe}^{2+}$ & 0.002 & 0.002 & 0.001 \\
$\mathrm{M} 3$ & $\mathrm{Mg}$ & 0.376 & 0.377 & 0.390 \\
& $\mathrm{Fe}^{2+}$ & 0.025 & 0.026 & 0.002 \\
& $\mathrm{Fe}^{3+}$ & 0.098 & 0.096 & 0.108 \\
$\mathrm{M} 4$ & $\mathrm{Mg}^{2+}$ & 0.059 & 0.070 & 0.081 \\
& $\mathrm{Fe}^{2+}$ & 0.001 & 0.001 & 0.003 \\
& $\mathrm{Al}^{3+}$ & 0.093 & 0.083 & 0.118 \\
& $\mathrm{Fe}^{3+}$ & 0.839 & 0.840 & 0.794 \\
& & & & \\
\hline
\end{tabular}




\section{LUDWIGITE FROM CENTRAL SWEDEN}

ludwigite by Takéuchi and Kogure (1992) and by Norrestam et al. (1989b), whereas the $\langle\mathrm{M} 2-\mathrm{O}\rangle$ band length is slightly smaller than that in ludwigite reported by Bonazzi and Menchetti (1989) who found small amounts of $\mathrm{Fe}^{2+}$ at this site.

In the M4 cavity, trivalent cations $\left(\mathrm{Fe}^{3+}\right.$ and $\mathrm{Al}^{3+}$ ) dominate over $\mathrm{Mg}$ (and $\mathrm{Fe}^{2+}$ ). Significantly different octahedral site occupancies for the M3 and M4 sites (our notation) have been found in ludwigite-type structures: ludwigite and vonsenite crystals studied by Bonazzi and Menchetti (1989) contain significant levels of trivalent cations at both the M3 and M4 sites, whereas in fredrikssonite, trivalent cations were located only at the M4 site. The distortion parameter BLD indicates that $\mathrm{M} 3$ is the most regular, whereas M4 is the most distorted polyhedron. However, the M4 distortion decreases in vonsenite; the $\mathrm{Fe}^{2+}, \mathrm{Fe}^{3+}$ end-member (Bonazzi and Menchetti, 1989: BLD $\mathrm{M}_{4}=2.00$ and $1.84 \%$ for samples RS and $\mathrm{Ca}$, respectively), and increases slightly in the Al-bearing ludwigites (Takéuchi and Kogure, 1992: BLD $_{\mathrm{M} 4}=2.99 \%$; Norrestam et al, $1989 a: \mathrm{BLD}_{\mathrm{M} 4}=3.17 \%$ ).

The results for studied crystals support the general idea that ludwigite is an order-disorder series where the cation disorder mostly involves the M3 and M4 sites. Like previously studied ludwigites (Norrestam et al, 1989a; Takéuchi and Kogure, 1992; Bonazzi and Menchetti, 1989), the crystals from Sweden, which have very low Al content, present $\mathrm{Mg}$ ordered at the $\mathrm{M} 1$ and $\mathrm{M} 2$ sites, whereas the $\mathrm{Mg}$ and the $\mathrm{Fe}^{3+}+\mathrm{Al}$ occupancy at the M3 and M4 sites, respectively, is significantly less than the ideal value of 1.0 for a completely ordered end-member.

\section{Acknowledgements}

This work was supported by Ministero dell'Università e della Ricerca Scientifica (project Relations between structure and properties of minerals: analysis and applications) and by Consiglio Nazionale delle Ricerche (CNR) of Italy. The CNR is also acknowledged for financing the Electron Microprobe Laboratory at Modena University.

P.W.U. Appel's fieldwork in Bergslagen 1997 was financed partly by an EEC-funded network (Hydrothermal alteration and sea-floor mineralization, contract no. CHRX-CT93-0314). The paper is published with the permission of the Geological Survey of Denmark and Greenland.

\section{References}

Anovitz, L.M. and Grew, E.S., eds. (1996) Mineralogy, petrology and geochemistry of boron: an introduction. In Boron, Mineralogy, Petrology and Geochemistry, Reviews in Mineralogy, (Min. Soc. America), 33, 1-40.

Bertaut, E.F. (1950) Structures des boroferrites. Acta Crystallogr., 3, 473-4.

Bonazzi, P. and Menchetti, S. (1989) Contribution to the crystal chemistry of the minerals of the ludwigitevonsenite series. Neues Jahrb. Miner. Mh, 1989, 69-83.

Burns, P.C., Cooper, M.A. and Hawthorne, F.C. (1994) Jahn-Teller-distorted $\mathrm{Mn}^{3+} \mathrm{O}_{6}$ octahedra in fredrikssonite, the fourth polymorph of $\mathrm{Mg}_{2} \mathrm{Mn}^{3+}\left(\mathrm{BO}_{3}\right) \mathrm{O}_{2}$. Canad. Mineral., 32, 397-403.

Cavalho da Silva, J., Clark, J.R. and Christ, C.L (1955) Crystal structure of ludwigite, $\mathrm{Mg}_{2} \mathrm{Fe}^{3+} \mathrm{BO}_{3} \mathrm{O}_{2}$. Geol. Soc. Amer. Bull., 66, 1540-1.

Fleischer, M. and Mandarino, J.A. (1995) Glossary of Mineral Species 1995. The Mineralogical Record, Tucson, Arizona.

Geijer, P. (1927) Some mineral associations from the Norberg District. Sver. Geol. Unders. Ser. C, 343, 32 pp.

Geijer, P. (1939) The paragenesis of ludwigite in Swedish Iron Ores. Geol. Foren Forh. Stockholm, 61, 19-33.

Hawthorne, F.C. (1986) Structural hierarchy in ${ }^{\mathrm{VI}} \mathrm{M}_{\mathrm{x}}{ }^{\mathrm{III}} \mathrm{T}_{\mathrm{y}} \phi_{\mathrm{z}}$ minerals. Canad. Mineral., 24, 625-42.

Hawthorne, F.C. and Grice, J.D., eds. (1990) Crystal structure analysis as a chemical analytical method: application to light elements. Canad. Mineral., 28, $693-702$.

Hawthorne, F.C., Burns, P.C. and Grice, J.D. (1996) The crystal chemistry of boron. In: Boron, mineralogy, petrology and geochemistry, Reviews in Mineralogy, (Min. Soc. America), 33, 41-115

Ibers, J.A. and Hamilton, W.C., eds. (1974) International Tables for X-ray Crystallography, IV. The Kynoch Press, Birminghan, UK.

Magnusson, N.H. (1929) Nordmarks malmtrakt. Sver geol. Unders. Ser. Ca., 23, $98 \mathrm{pp}$.

Merlino, S. and Perchiazzi, N. (1988) Modular mineralogy in the cuspidine group of minerals. Canad. Mineral., 26, 933-43.

Mokeyeva, V.L. (1968) Refinement of structure of

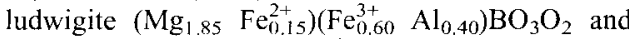
distribution of $\mathrm{Mg}^{2+}$ and $\mathrm{Fe}^{2+}$ among the cation sites of the structure. Geochem. Intern., 5, 809-13.

Moore, P.B. and Araki, T. (1976) Painite, $\mathrm{CaZrB}\left[\mathrm{Al}_{9} \mathrm{O}_{18}\right]$ : Its crystal structure and relation to jeremejevite, $\mathrm{B}_{5}\left[\square_{3} \mathrm{Al}_{6}(\mathrm{OH})_{3} \mathrm{O}_{15}\right]$, and fluoborite, $\mathrm{B}_{3}\left[\mathrm{Mg}_{9}(\mathrm{~F}, \mathrm{OH})_{9} \mathrm{O}_{9}\right]$. Amer. Mineral., 61, 88-94.

Norrestam, R., Dahl, S. and Bovin, J.-O. (1989a) The 
structure of magnesium-aluminium ludwigite, $\mathrm{Mg}_{2.11} \mathrm{Al}_{0.31} \mathrm{Fe}_{0.53} \mathrm{Ti}_{0.05} \mathrm{Sb}_{0.01} \mathrm{BO}_{5}$, a combined single crystal X-ray and HREM strudy. Zeits. Kristallogr., 187, 201-11.

Norrestam, R., Nielsen, K., Søtofte, I. and Thorup, N. (1989b) Structural investigation of two synthetic oxyborates: the mixed magnesium-manganese and the pure cobalt ludwigites, $\mathrm{Mg}_{1.93(2)} \mathrm{Mn}_{1.07(2)} \mathrm{O}_{2} \mathrm{BO}_{3}$ and $\mathrm{CO}_{3} \mathrm{O}_{2} \mathrm{BO}_{3}$. Zeits. Kristallogr., 189, 33-41.

Renner, B. and Lehmann, G. (1986) Correlation of angular and bond length distortion in $\mathrm{TO}_{4}$ unit in crystals. Zeits. Kristallogr., 175, 43-59.

Sheldrick, G.M. (1997) The SHELX-97 manual. University of Göttingen, Germany.

Siemens (1993) XSCANS System-technical Reference.
Siemens Analytical X-ray Instruments.

Swinnea, J.S. and Steinfink, H. (1983) Crystal structure and Mössbauer spectrum of vonsenite, $2 \mathrm{FeO} \times \mathrm{FeBO}_{3}$. Amer. Mineral., 68, 827-32.

Takéuchi, Y. and Kogure, T.(1992) The structure type of ludwigite. Zeits. Kristallogr., 200, $161-7$.

Takéuchi, Y., Watanabé, T. and Ito, T. (1950) The crystal structures of warwickite, ludwigite and pinakiolite. Acta Crystallogr., 3, 98-107.

Venkatakrishnan, V. and Buerger, M.J. (1972) The crystal structure of $\mathrm{FeCoOBO}_{3}$. Zeits. Kristallogr., $135,321-38$.

[Manuscript received 24 March 1998:

revised 22 October 1998] 